University of Michigan Law School

University of Michigan Law School Scholarship Repository

Articles

Faculty Scholarship

1917

\title{
The Patentability of a Principle of Nature
}

John B. Waite

University of Michigan Law School

Available at: https://repository.law.umich.edu/articles/1345

Follow this and additional works at: https://repository.law.umich.edu/articles

Part of the Intellectual Property Law Commons, Science and Technology Law Commons, and the Supreme Court of the United States Commons

\section{Recommended Citation}

Waite, John B. "The Patentability of a Principle of Nature." Mich. L. Rev. 15, no. 3 (1917): 243-5.

This Response or Comment is brought to you for free and open access by the Faculty Scholarship at University of Michigan Law School Scholarship Repository. It has been accepted for inclusion in Articles by an authorized administrator of University of Michigan Law School Scholarship Repository. For more information, please contact mlaw.repository@umich.edu. 
The Patentability of a Principle of Nature-The extent to which courts will go in conceding patentability to a natural law, or principle of nature, is evidenced in the case of Mintrals Separation Co. v. Hyde, 37 Sup. Ct. -, decided by the Supreme Court, December II, I916. It has always been more or less an axiom of patent law that the discovery of a principle of nature does not entitle the discoverer to a patent for it. The case usually thought of first as authority therefor, is that of Morton v. New York Eye Infirmary, 5 Blatch. I16, 2 Fisher 320 . The patentees in that case had discovered that the inhalation of sulphuric ether would produce insensibility to pain. The ether itself was well known and the means by which the patentees induced it to the lungs was not new. It was the effect produced by its induction to the lungs which, alone, had been theretofore unknown. On this showing the court held the patent to be invalid, saying, "A discovery of a new principle, force, or law, operating, or which can be made to operate, on matter, will not entitle the discoverer to a patent." "The new force or principle brought to light must be embodied and set to work, and can be patented only in connection or combination with the means by which, or the medium through which, it operates." Another frequently cited case upon this proposition is that of O'Reilly v. Morse, 15 How. 62. The eighth claim of the patent involved in that case was for "the use of the motive power of the electric or galvanic current, which I call electro-magnetism, however, developed for marking or printing intelligible characters, signs or letters at any distances, being a new application of that power of which I claim to be the first inventor or discoverer." This claim was held invalid, on the ground that it was too broad and did not describe any means by which the force was to be utilized.

In the Morton case, patentability was denied the discovery despite the court's statement that a new force or principle could be patented in connection or combination with means through which it was made to operate. Two reasons for this denial are possible of deduction from the case-though no reason is explicitly stated. One is that the principle was not in reality a principle at all, but was itself the result, the end sought. It could not, in this view of it, be considered as operating "in connection with" any means. It must have been not a correlated "means," but the "effect" of some means. In this view, the statement of the court is sound, but quite irrelevant to the question before it. The other possibility is that the court believed the means in connection with which the principle was used ought itself to be new. 
As the means of inducing the ether to the lungs used by Morton was old, the invalidity of the patent would follow.

This view of the law was accepted by the Supreme Court in the case of LeRoy v. Tatham, i4 How. 155. The patentees had discovered that lead would re-unite after separation, if under heat and great pressure even though not in a wholly fluid state. By this discovery they were enabled to make lead pipe much more economically and of better quality than had been possible. The apparatus they used, however, was apparently similar, except in size, to that which was used in other industries. The trial court, in an action at law, charged the jury that the invention "did not consist in the novelty of the machinery, but in bringing a newly discovered principle into practical application, by which a useful article of manufacture is produced." The patentees had not claimed as their invention any of the parts of the machinery, but only the combination thereof when used for the purpose of forming pipes of metal, under heat and pressure, in the manner set forth. The Supreme Court reversed the case for error in the trial court's instruction, on the ground that the machinery being old, the alleged invention was only, "at most, an old invention, or apparatus or machinery applied to a new purpose," and that, "if it is old and well known, and applied only to a new purpose, that does not make it patentable." The court does not seem to have considered that the inyention could possibly have been what the patentee appeared to have claimed, namely, the combination of old substantial means and a new force of nature, to constitute, as a whole, a new idea of means.

This same case came before the court again, in equity, and the opinion was again delivered by Mr. Justice McLEAN. The court sustained the validity of the patent. It is impossible to ascertain from the opinion on just what grounds. It is said, "One new and operative agency in the production of the desired result would give novelty to the entire combination." This new agency might have been the newly discovered principle, but there is an intimation contextually that there was some new, but unnamed, substantial part in the particular combination used. (While this is the implication of the immediate context, the court had earlier said, "the machinery used was admitted to be old.")

The facts of the Mizerals Separation Co. case were very closely analogous to those of LeRoy v. Tatham. The patent was for a process of separating mineral matter from the rock in which it had been born, after the latter had been crushed. Prior to the patent, this had been accomplished by the use of oil and water. The affinity of oil for mineral being greater than for the rocky matter, it caused an agglomeration of the former. Upon agitation of the whole mass in water, the buoyancy of the oil, if enough had been used, caused it to rise to the surface, bearing the mineral matter with it. It could then be floated off from the other matter. If less oil were used, its agglomeration of mineral matter caused it to stay at the bottom while agitation of the water bore upward and away the lighter particles of rock. Either of these methods required the use of a costly amount of oil. While the patentees were experimenting for a method of reducing the amount of oil necessary, they discovered that after a certain reduction the agglomera- 
tion and separation of the mineral matter ceased, but that after a still further reduction, it apparently began again. This renewed separation was not due to the agglomerating and lifting force of the oil, but to the fact that the minute quantity of oil in the water caused bubbles of air, introduced by the agitation of the mass, to remain for a time undissipated from the surface. These bubbles attached themselves to the particles of mineral and caused such particles to float clear of the rocky material. A patent was granted for this process.

The process of the patentees was old in all respects except that of the principle involved. As the Circuit Court of Appeals said (214 Fed. IOO, IO9), "each step in their process is fully described in more than one of the patents of the prior art, with the single exception of the reduced quantity of oil which they use." That court, therefore, held the patent to be invalid. The Supreme Court reversed this decision, on the sole expressed ground that the "advance on the prior art and the resulting froth concentrate, so different from the product of other processes, make of it a patentable discovery as new and original as it has proved useful and economical." The invention must have lain in the reduction of the amount of oil, but this change, in itself, was too slight to have constituted a new process. The process was new because, by the reduction in amount of oil, it utilized a new principle, or principles, of nature. So many other cases have distinguished between apparently similar processes or machines because of a difference in their "principles of operation" that it is unnecessary to cite particular authority, but the case just discussed reveals the effect of the principle used with especial clearness. It is undoubtedly true that a principle of nature or a natural force can not by itself be monopolized by patenting, but it seems equally true that, like substantial wheels and levers, and other individually unpatentable things, a principle of nature, as the only new part of a novel combination, is often patented to the extent of its use in such combination or its equivalents.

J. B. W. 